\title{
Laboratory markers of diabetes mellitus in the elderly
}

\author{
D Foti", M Greco, M Falbo, V Ventura, F Accattatto, E Gulletta \\ From de Senectute: Age and Health Forum \\ Catanzaro, Italy. 5-7 December 2009
}

\section{Background}

Diabetes mellitus is a leading cause of morbidity and mortality in Western countries. To prevent diabetic chronic complications, various trials have validated the need for tight glycemic control [1]. Important laboratory markers used in the follow-up of diabetic patients include glycated hemoglobin (HbA1c) $[2,3]$ and microalbuminuria [3], an important predictor of diabetic nephropathy.

The aim of this study is to evaluate HbA1c as a significant index of glycemic control, and to determine the prevalence of microalbuminuria in elderly diabetic patients in our geographic area.

\section{Materials and methods}

HbA1c levels were measured using a high-pressure liquid chromatography methodology (HA 8160, Menarini Diagnostics), and analysed in 352 consecutive diabetic patients (age: $>41$ years) within a two month time period (September-October 2009). The optimal HbA1c target for diabetic patients was considered $<7 \%$, as recommended by the American Diabetes Association. Urinary albumin levels were measured by an immunoturbidimetric assay (BN II, Dade Behring) in 226 consecutive diabetic patients (age: $>41$ years) within the same time period. Microalbuminuria was diagnosed if albumin in urine samples was $>30 \mathrm{mg} / \mathrm{L}$.

\section{Results}

Within the patients examined, the overall $\mathrm{HbA1c}$ mean is $6.95 \%+1.51$, and the overall prevalence of high HbA1c (>7\%), indicative of poor glycemic control, is $34.4 \%$. Interestingly, the prevalence of patients with high HbA1c is over $30 \%$ in any age range examined, with a peak in the age range 61-70 (Table 1). However, while

Chair of Clinical Pathology, Department of Experimental and Clinical Medicine, University of Catanzaro "Magna Graecia", Catanzaro, 88100, Italy
Table 1

\begin{tabular}{lll}
\hline $\begin{array}{l}\text { Age range and } \\
\text { number of patients }\end{array}$ & HbA1c (mean+SD) & $\begin{array}{l}\text { Patients with } \\
\text { HbA1c > 7\% }\end{array}$ \\
\hline $41-50(n=49)$ & $6.58 \%+1.82$ & $16(32.6 \%)$ \\
$51-60(n=85)$ & $7.10 \%+1.74$ & $27(31.8 \%)$ \\
$61-70(n=112)$ & $7.14 \%+1.53$ & $46(41.1 \%)$ \\
71 and over $(n=106)$ & $6.86 \%+1.07$ & $32(30.2 \%)$ \\
\hline
\end{tabular}

Table 2

\begin{tabular}{ll}
\hline $\begin{array}{l}\text { Age range and number of } \\
\text { patients }\end{array}$ & $\begin{array}{l}\text { Patients with } \\
\text { microalbuminuria }\end{array}$ \\
\hline $41-50(n=48)$ & $4(8.3 \%)$ \\
$51-60(n=57)$ & $5(8.7 \%)$ \\
$61-70(n=62)$ & $17(27.4 \%)$ \\
71 and over $(n=59)$ & $17(28.9 \%)$ \\
\hline
\end{tabular}

the overall prevalence of microalbuminuria is $19.2 \%$, in agreement with data reported by the Italian Ministry of Health, microalbuminuria is diagnosed in about $8 \%$ of diabetics under 60 years, and in almost $30 \%$ of patients over 60 years (Table 2).

\section{Conclusions}

Our data indicate that a sub-optimal glycemic control is observed in more than $30 \%$ of the diabetics examined, regardless of age. Furthermore, our data confirm that older age is associated with an increased risk of microalbuminuria and progressive impairment of renal function.

Published: 19 May 2010

\section{References}

1. UK Prospective Diabetes Study (UKPDS) Group: Intensive blood-glucose control with sulphonylureas or insulin compared with conventional treatment and risk of complications in patients with type 2 diabetes (UKPDS 33). Lancet 1998, 352:837-853. 
2. Qaseen A, Vijan S, Snow V, Cross JT, Weiss KB, Owens DK: Glycemic control and type 2 diabetes mellitus: the optimal hemoglobin A1c targets. A guidance statement from the American College of Physicians. Ann Intern Med 2007, 162(z):417-422.

3. American Diabetes Association: Standards of Medical Care in Diabetes2009. Diabetes Care 2009, 32(z):S13-S61.

doi:10.1186/1471-2318-10-S1-A108

Cite this article as: Foti et al: Laboratory markers of diabetes mellitus in the elderly. BMC Geriatrics 2010 10(Suppl 1):A108.

Submit your next manuscript to BioMed Central and take full advantage of:

- Convenient online submission

- Thorough peer review

- No space constraints or color figure charges

- Immediate publication on acceptance

- Inclusion in PubMed, CAS, Scopus and Google Scholar

- Research which is freely available for redistribution

Submit your manuscript at www.biomedcentral.com/submit 